\title{
Excellent Cyclic and Rate Performances of SiO/C/Graphite Composites as Li-Ion Battery Anode
}

\author{
Long $\mathrm{Hu}^{1}$, Wenming $\mathrm{Xia}^{1}$, Renheng Tang ${ }^{2 \star}$, Renzong $\mathrm{Hu}^{1}$, Liuzhang Ouyang ${ }^{1}$, Tai Sun ${ }^{2}$ \\ and Hui Wang ${ }^{1 *}$
}

${ }^{1}$ Guangdong Provincial Key Laboratory of Advanced Energy Storage Materials, School of Materials Science and Engineering, South China University of Technology, Guangzhou, China, ${ }^{2}$ Guangdong Province Key Laboratory of Rare Earth Development and Application, Guangdong Research Institute of Rare Metals, Guangzhou, China

\section{OPEN ACCESS}

Edited by:

Wenping Sun

Zhejiang University, China

Reviewed by:

Kun Rui,

Nanjing Tech University, China

Xinxin Cao,

Central South University, China

*Correspondence:

Renheng Tang

tangrenhgz@163.com

Hui Wang

mehwang@scut.edu.cn

Specialty section:

This article was submitted to

Electrochemistry,

a section of the journal

Frontiers in Chemistry

Received: 23 January 2020 Accepted: 14 April 2020

Published: 15 May 2020

Citation:

Hu L, Xia W, Tang R, Hu R, Ouyang L,

Sun $T$ and Wang $H$ (2020) Excellent

Cyclic and Rate Performances of

SiO/C/Graphite Composites as Li-Ion

Battery Anode. Front. Chem. 8:388

doi: 10.3389/fchem.2020.00388
The SiO-based composites containing different carbon structures were prepared from asphalt and graphite by the milling, spray drying, and pyrolysis. In the obtained near-spherical composite particles, the refined amorphous SiO plates, which are coated with an amorphous carbon layer, are aggregated with the binding of graphite sheets. The $\mathrm{SiO} / \mathrm{C} /$ Graphite composites present a maximum initial charge capacity of $963 \mathrm{mAh}^{-1}$ at $100 \mathrm{~mA} \mathrm{~g}^{-1}$, excellent cyclic stability ( $950 \mathrm{mAh} \mathrm{g}^{-1}$ over 100 cycles), and rate capability with the charge capacity of $670 \mathrm{mAh} \mathrm{g}^{-1}$ at $1,000 \mathrm{~mA} \mathrm{~g}^{-1}$. This significant improvement of electrochemical performances in comparison with pristine $\mathrm{SiO}$ or $\mathrm{SiO} / \mathrm{C}$ composite is attributed to the unique microstructure, in which both the graphite sheets and amorphous carbon coating could enhance the conductivity of $\mathrm{SiO}$ and buffer the volume change of $\mathrm{SiO}$. The higher pyrolysis temperature causes the denser spherical microstructure and better cycle life. Our work demonstrates the potential of this SiO/C/Graphite composite for high capacity anode of LIBs.

Keywords: lithium-ion battery, SiO, spray drying, pyrolysis, cyclic stability

\section{INTRODUCTION}

With the rapid development of portable electronic devices and plug-in hybrid electric vehicles, high-capacity anode materials are urgently essential to satisfy the ever-increasing energy storage density requirements of LIBs (Krywko-Cendrowska et al., 2013; Song et al., 2013; Yamamura et al., 2013; Yu et al., 2014), since the theoretical specific capacity of commercial graphite anode is limited to $372 \mathrm{mAh} \mathrm{g}^{-1}$ (Wu et al., 2014; Li et al., 2015; Wang et al., 2015; Fu et al., 2018). Silicon (Si) is one of the most promising anode materials for the next-generation Li-ion batteries because of its super-high theoretical capacity $\left(4,200 \mathrm{mAh} \mathrm{g}^{-1}\right.$, corresponding to $\mathrm{Li}_{22} \mathrm{Si}_{5}$ alloy) (Si et al., 2011; Zeilinger et al., 2013; Liang et al., 2014; Su et al., 2014; Lee et al., 2019). However, its drastic volume expansion (>300\%) during the lithiation/delithiation process readily causes the pulverization and cracking of electrode and a rapid fading of cyclic capacity, hindering its commercial applications (Wang et al., 2011; Yamada et al., 2013; Rahman et al., 2016). Recently, various approaches have been adopted to develop nano-sized silicon (Kataoka et al., 2016; Jia et al., 2018), silicon-based composites (Huang et al., 2013; Yang et al., 2018), and silicon oxides (Lv et al., 2013), which could effectively overcome the pulverization problem of $\mathrm{Si}$ anode, and significantly improve the cyclic performance.

Silicon monoxide $(\mathrm{SiO})$ also presents rather high specific capacity $\left(2,400 \mathrm{mAh}^{-1}\right)$ (Li et al., 2013; Wang et al., 2014). Compared with pure $\mathrm{Si}$, the volume change of $\mathrm{SiO}(200 \%)$ is significantly 
decreased due to the introduction of oxygen. Theoretically, the cyclic capability of $\mathrm{SiO}$ should be more stable than Si. However, the $\mathrm{SiO}$ suffers from a lower intrinsic conductivity (6.7 $\times 10^{-4} \mathrm{~S} \cdot \mathrm{cm}^{-1}$ ) (Hou et al., 2015). Additionally, the reaction of $\mathrm{SiO}$ with $\mathrm{Li}^{+}$produces much inert $\mathrm{Li}$-oxide $\left(\mathrm{Li}_{2} \mathrm{O}\right)$ and $\mathrm{Li}$ silicate $\left(\mathrm{Li}_{4} \mathrm{SiO}_{4}\right)$ (Kim et al., 2013; Lv et al., 2015), which would lead to large initial irreversible capacity and low initial Coulombic efficiency (Kim et al., 2011; Yom et al., 2016). For that, carbonaceous materials or metals are used as useful additives to form nanocomposite structure, which could not only enhance electronic conductivity but also buffer the volume change. Thus, the electrochemical performances of $\mathrm{SiO}$ could be markedly improved. Wang et al. (2011) prepared the $\mathrm{SiO} / \mathrm{C}$ composite by the modified Stöber method, which exhibited a capacity of $800 \mathrm{mAh} \mathrm{g}^{-1}$ after 50 cycles. Yuan et al. (2015) prepared the $\mathrm{SiO} / \mathrm{C}$ composite by a hydrothermal process, which exhibited a capacity of $744 \mathrm{mAh} \mathrm{g}^{-1}$ at $0.1 \mathrm{C}$ after 50 cycles. The other method is to utilize the disproportionation reaction of $\mathrm{SiO}$ into the $\mathrm{Si} / \mathrm{SiO}_{2}$ system, within which the $\mathrm{SiO}_{2}$ matrix could buffer the enormous volume change of Si. For example, Hwa et al. (2013) prepared the modified $\mathrm{SiO}$ electrode by the disproportionation reaction, which exhibited a capacity of $c a .1,000 \mathrm{mAh} \mathrm{g}^{-1}$ over 50 cycles. Zhang et al. (2019) developed C-SiO- $\mathrm{MgSiO}_{3}-\mathrm{Si}$ secondary super-particles to address the low ICE, which exhibited the highest ICE of $78.3 \%$ with a high initial capacity of 1,608 $\mathrm{mAh}$ $\mathrm{g}^{-1}$. Xu et al. (2017) synthesized novel $\mathrm{SiO}_{\mathrm{x}} /$ asphalt membrane via demulsification of porous $\mathrm{SiO}_{\mathrm{x}}$ microspheres. The $\mathrm{SiO}_{\mathrm{x}} / \mathrm{C} / \mathrm{G}$ anode retained a reversible capacity of $541 \mathrm{mAh} \mathrm{g}^{-1}$ after 600 cycles at $0.2 \mathrm{~A} \mathrm{~g}^{-1}$.

In this study, a spherical composite of amorphous SiO, amorphous carbon, and graphite was obtained by the preparation process of mechanical milling, spray drying, and heat-treatment. The obtained SiO-based composites exhibited excellent cyclic capacity. The effect of heat-treatment temperature and graphite addition on the electrochemical performances was investigated.

\section{EXPERIMENTAL}

\section{Preparation of SiO-Based Composites}

The preparing process of $\mathrm{SiO} / \mathrm{C} / \mathrm{G}$ composites is schematically shown in Figure 1. The raw materials of $\mathrm{SiO}$, asphalt and graphite were mixed with the mass ratio 3:1:1 and placed in a beaker filled with $400 \mathrm{ml}$ solvent containing 50\% deionized water and $50 \%$ ethanol. The obtained precursor solution was mechanically milled at 2,800 rpm for $3 \mathrm{~h}$, using Zirconium oxide balls of $2 \mathrm{~mm}$ diameter, with a ball to powder mass ratio of 20:1. After that, using a sieve to separate the slurry from balls. Then, the separated slurry was dried by spray drying under the following technological conditions: the air-feeding temperature $340^{\circ} \mathrm{C}$, the air-outlet temperature $140^{\circ} \mathrm{C}$, and the flowing rate $25 \mathrm{ml} \cdot \mathrm{min}^{-1}$. Finally, the prepared precursor was heated up to 700 and $900^{\circ} \mathrm{C}$ at a rate of $3^{\circ} \mathrm{C} \min ^{-1}$ under nitrogen atmosphere and kept for $3 \mathrm{~h}$ in a tube furnace, the obtained composites heated at 700 and $900^{\circ} \mathrm{C}$ were termed as $\mathrm{SiO} / \mathrm{C} / \mathrm{G}-700$ and $\mathrm{SiO} / \mathrm{C} / \mathrm{G}-900$, respectively. For comparison, the $\mathrm{SiO} / \mathrm{C}$ composite without the addition of graphite was also prepared by the same preparing process from $\mathrm{SiO}$ and asphalt with the mass ratio of $3: 1$ at the pyrolysis temperature of $700^{\circ} \mathrm{C}$, the obtained composite was termed as $\mathrm{SiO} / \mathrm{C}-700$.

\section{Structural Characterization}

The structures of the prepared composites were characterized by using X-ray diffraction (XRD, Philips X'Pert MPD, Cu $\mathrm{K} \alpha$ ), scanning electron microscopy (SEM, Zeiss supra 40), Transmission electron microscope (TEM, JEOL 2100) operating at $200 \mathrm{kV}$, the Fourier Transform Infrared Reflection (FTIR, Bruker Vector 33), and laser Raman spectroscopy (HORIBA Labram) with an excitation wavelength of $632.8 \mathrm{~nm}$. Thermogravimetric analysis (TG, Netzsch STA 449C) was performed to determine the carbon content and the pyrolysis temperature of the composites at a heating rate of $5 \mathrm{~K} \cdot \mathrm{min}^{-1}$ with $\mathrm{N}_{2}$ flowing rate of $30 \mathrm{ml} \cdot \mathrm{min}^{-1}$.

\section{Electrochemical Measurement}

The electrochemical performances of as-prepared composites were evaluated using 2,032 coin half-cells. The coin cells were assembled in an Ar-filled glove box. The working electrodes of tested cells were fabricated by pasting mixture slurry consisting of various active materials, acetylene black $(\mathrm{AB})$ as conductive agent and carboxymethyl cellulose (CMC) as binder at a weight ratio of 60:20:20 onto a copper foil $\left(10 \mathrm{~cm}^{2}, 99.9 \%\right)$, the mass loading for the electrodes was $0.65-0.95 \mathrm{mg} \mathrm{cm}^{-2}$. The Li foil was used as the counter electrode and reference electrode. Porous polypropylene (Celgard 2500) was used as the separator, and the electrolyte is $1 \mathrm{M} \mathrm{LiPF} 6$ dissolved in a mixed solvent of ethylene carbonate (EC), dimethyl carbonate (DMC) and ethyl methyl carbonate (EMC) (1:1:1 by volume). The galvanostatic cycling test is carried out with Land CTR 2001A Tester at different current densities in the voltage range of $0.01-1.5 \mathrm{~V}$ vs. $\mathrm{Li}^{2} \mathrm{Li}^{+}$to measure the specific capacity, rate capability and Coulombic efficiency.

\section{RESULTS AND DISCUSSION}

\section{Microstructural Analysis}

Figure 2A shows the XRD patterns of pristine $\mathrm{SiO}$ and the asprepared composites. For the pristine $\mathrm{SiO}$, the broad scattering peak ranging $15-35^{\circ}$ is assigned to amorphous $\mathrm{SiO}$, and the weak Si (111) diffraction indicates that a small amount of crystalline Si retained in the amorphous SiO. The XRD pattern of $\mathrm{SiO} / \mathrm{C}-700$ composite does not show any diffraction peaks, suggesting that the asphalt transformed to amorphous carbon at the pyrolysis temperature of $700^{\circ} \mathrm{C}$. Meanwhile, the retained $\mathrm{Si}$ in the raw $\mathrm{SiO}$ should be oxidized to amorphous $\mathrm{SiO}$ during milling. Sharp Bragg peaks of graphite are present in the XRD patterns of both $\mathrm{SiO} / \mathrm{C} / \mathrm{G}-700$ and $\mathrm{SiO} / \mathrm{C} / \mathrm{G}-900$ composites. Especially for the $\mathrm{SiO} / \mathrm{C} / \mathrm{G}-900$ composite, the appearance of $\mathrm{Si}$ diffractions implies the partial thermal reduction reaction of $\mathrm{SiO}$ with carbon at $900^{\circ} \mathrm{C}$, which could not occur at $700^{\circ} \mathrm{C}$ for the $\mathrm{SiO} / \mathrm{C} / \mathrm{G}-700$ composite.

To determine the content of amorphous carbon in the composites, TG analysis was performed on the $\mathrm{SiO} /$ Asphalt and $\mathrm{SiO} / \mathrm{Asphalt} / \mathrm{Graphite}$ composites by spray drying, and the results are shown in Figure 2B. The weight loss is due to the dehydration-condensation reaction and thermal decomposition 


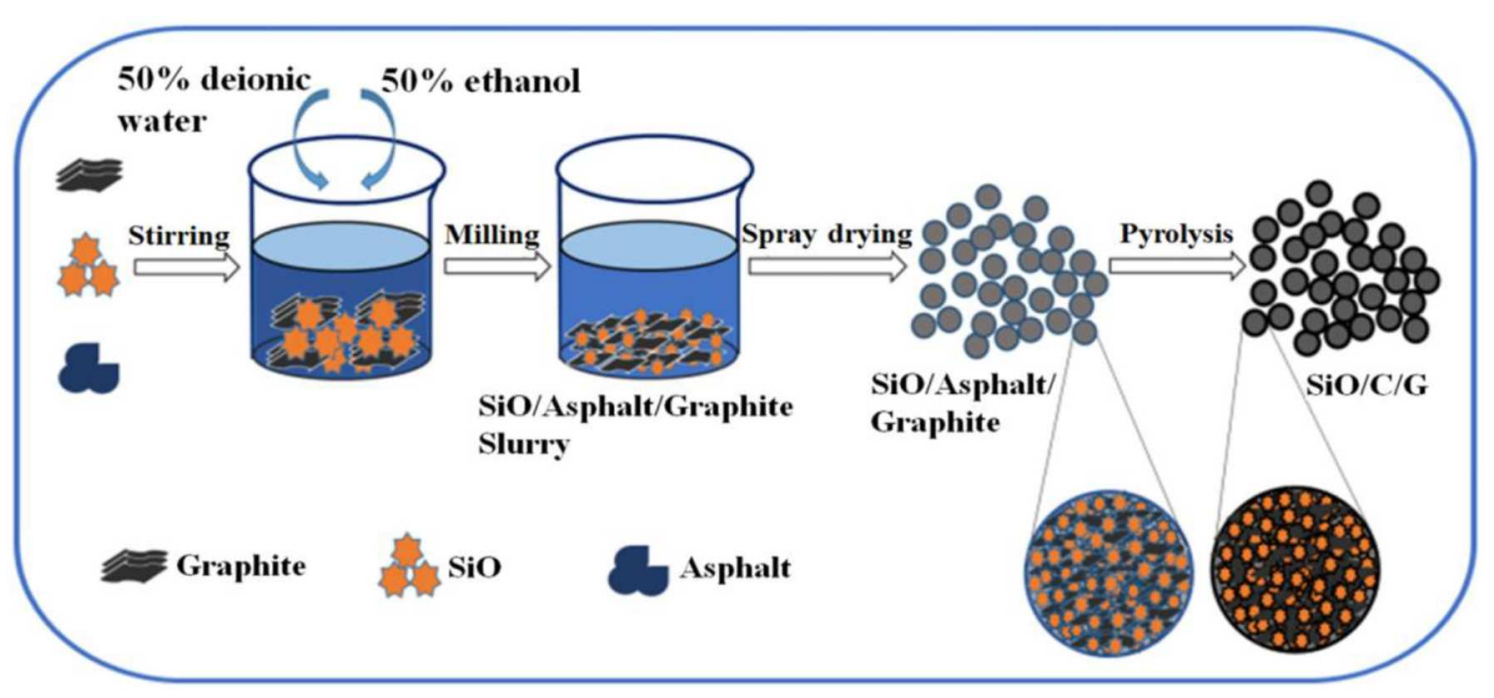

FIGURE 1 | Scheme 1 Schematic representation of the synthetic process of SiO/C/G composites.
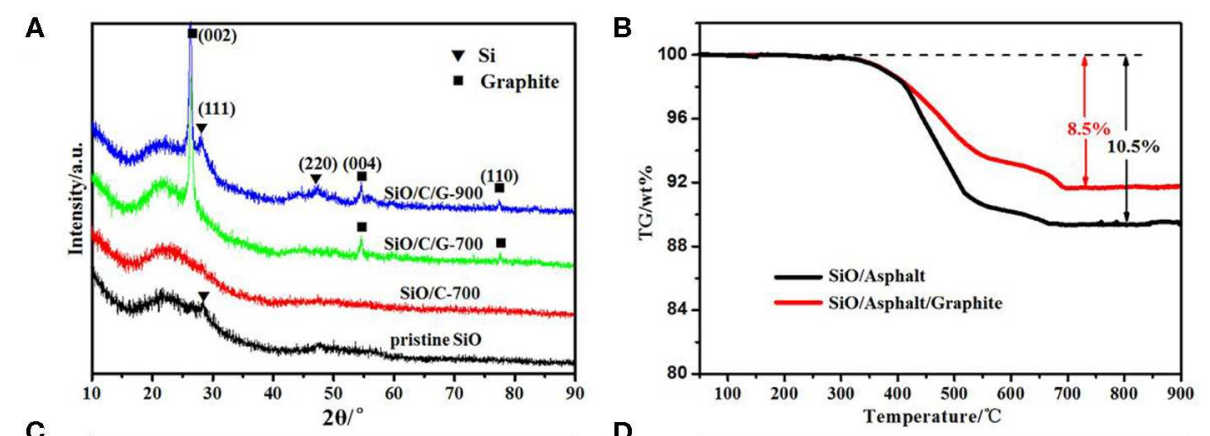

C

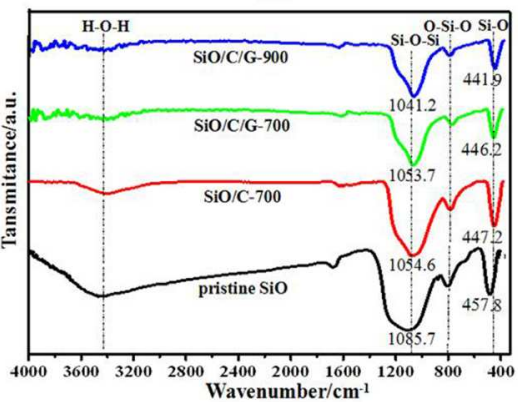

D

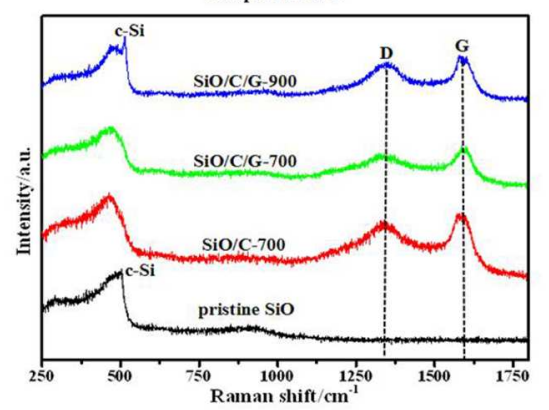

FIGURE 2 | Pristine SiO, SiO/C-700, SiO/C/G-700, and SiO/C/G-900 composites material: (A) XRD patterns. (B) TG curves of SiO/Asphalt and SiO/Asphalt/G composites. (C) FTIR spectra. (D) Raman spectra.

of super polymer in asphalt. Above $700^{\circ} \mathrm{C}$, the TG curves remain almost unchanged, indicating the complete decomposition of asphalt. Therefore, the pyrolysis temperature of $\mathrm{SiO} /$ Asphalt and $\mathrm{SiO} /$ Asphalt/Graphite was set above $700^{\circ} \mathrm{C}$. It is also shown in Figure 2B that the weight loss for the sprayed $\mathrm{SiO} /$ Asphalt composite (weight ratio 3:1) is 10.5 wt.\%. Therefore, the content of amorphous carbon in the heated composite $\mathrm{SiO} / \mathrm{C}-700$ is calculated to be ca. $16.2 \mathrm{wt} . \%$ and the fraction of $\mathrm{SiO}$ is 83.8 wt.\%. Similarly, for the SiO/C/G-700 composite, it consists of
12.6 wt.\% of amorphous carbon, 21.9 wt.\% of graphite and 65.5 wt.\% of $\mathrm{SiO}$. The $\mathrm{SiO} / \mathrm{C} / \mathrm{G}-900$ composite should have the same composition with the $\mathrm{SiO} / \mathrm{C} / \mathrm{G}-700$ composite, if not considering the reduction of partial $\mathrm{SiO}$ into $\mathrm{Si}$.

Figure 2C compares the FTIR spectra of pristine $\mathrm{SiO}$ and the as-prepared composites. For the pristine $\mathrm{SiO}$, the characteristic peaks at $1085.7 \mathrm{~cm}^{-1}, 802.0 \mathrm{~cm}^{-1}$, and $457.8 \mathrm{~cm}^{-1}$ are, respectively, attributed to asymmetric $\mathrm{Si}-\mathrm{O}-\mathrm{Si}$ stretching vibration, symmetric $\mathrm{O}-\mathrm{Si}-\mathrm{O}$ deformation vibration and $\mathrm{Si}-\mathrm{O}$ 
rocking vibration (Zheng and Li, 2014; Li et al., 2015). While for the $\mathrm{SiO} / \mathrm{C}-700$ and $\mathrm{SiO} / \mathrm{C} / \mathrm{G}$ composites, there appears obvious red shift for the Si-O-Si stretching vibration and Si-O rocking vibration. Especially for the $\mathrm{SiO} / \mathrm{C} / \mathrm{G}-900$ composite heated at a higher temperature, it exhibits the largest red shift to $1041.2 \mathrm{~cm}^{-1}$ and $441.9 \mathrm{~cm}^{-1}$. This red shift phenomenon could be explained by the decrease of $\mathrm{O} / \mathrm{Si}$ ratio in $\mathrm{SiO}_{x}(0<x \leqq 2)$ as previously reported in the literature (Chang et al., 2012; Hwa et al., 2013), it also confirms the thermal reduction reaction of $\mathrm{SiO}$ with carbon during pyrolysis.

Figure 2D compares the Raman spectra of $\mathrm{SiO}$ and the asprepared composites. For the pristine $\mathrm{SiO}$, the broad bands ranging from 400 to $550 \mathrm{~cm}^{-1}$ are assigned to amorphous $\mathrm{SiO}$ (Guo et al., 2014; Rahaman et al., 2016), while a sharp weak peak at $c a .520 \mathrm{~cm}^{-1}$ corresponds to crystalline $\mathrm{Si}(\mathrm{c}-\mathrm{Si})$. The $\mathrm{Si}$ peak disappears in the Raman spectra of $\mathrm{SiO} / \mathrm{C}-700$ and $\mathrm{SiO} / \mathrm{C} / \mathrm{G}-700$ composites but appears again for the $\mathrm{SiO} / \mathrm{C} / \mathrm{G}-$ 900 composite. This is well consistent with the XRD results as shown in Figure 2B. Compared with pure $\mathrm{SiO}$, there is no distinct change of amorphous $\mathrm{SiO}$ peak in the Raman spectra of three composites. Concerning the typical D-band at $1,345 \mathrm{~cm}^{-1}$ and G-band at $1,585 \mathrm{~cm}^{-1}$ in the Raman spectrum of $\mathrm{SiO} / \mathrm{C}-700$ composite, which confirms the transformation of asphalt into disordered carbon. Besides, the Raman spectra of $\mathrm{SiO} / \mathrm{C} / \mathrm{G}-700$ and $\mathrm{SiO} / \mathrm{C} / \mathrm{G}-900$ composites show similar D-band and G-band peaks with that of $\mathrm{SiO} / \mathrm{C}-700$ composite, despite the addition of graphite (Xiao et al., 2013; Vengudusamy et al., 2014).

Figure 3 shows the SEM images of pristine $\mathrm{SiO}$ and asprepared composites. The SEM observation from Figure 3a reveals the plate-like shape of pristine $\mathrm{SiO}$, which is in micrometer size. For the SiO/C-700 composite shown in Figures $3 \mathbf{b}, \mathbf{c}$, the spherical-like particles of $c a .15 \mu \mathrm{m}$ in diameter are observed, within which the $\mathrm{SiO}$ plates of ca. $500 \mathrm{~nm}$ size are loosely aggregated. Therefore, the milling greatly refined the size of $\mathrm{SiO}$ plates. As also shown in Figures $\mathbf{3 c}, \mathbf{f}$, it appears that the $\mathrm{SiO}$ plates are coated by pyrolytic amorphous carbon. As seen in Figures 3d,e, both the $\mathrm{SiO} / \mathrm{C} / \mathrm{G}-700$ and $\mathrm{SiO} / \mathrm{C} / \mathrm{G}-$ 900 composites present near-spherical particles, in which the graphite sheets are dispersive to fill the pores between $\mathrm{SiO}$ plates. The pores of $\mathrm{SiO} / \mathrm{C} / \mathrm{G}-900$ composites are finer because the disproportionation and thermal reduction reactions are more complete at higher pyrolysis temperature. Therefore, the $\mathrm{SiO} / \mathrm{C} / \mathrm{G}-900$ composite particles are denser than the SiO/C700 composite.

The microstructure of $\mathrm{SiO} / \mathrm{C} / \mathrm{G}-900$ composite is further characterized by TEM. Figure $\mathbf{4 A}$ shows the $\mathrm{SiO}$ is evenly distributed over the graphite sheets. As seen in Figure 4B, the $\mathrm{SiO}$ is wrapped with amorphous carbon layer of the thickness of $\sim 10 \mathrm{~nm}$. Overall, the multi-phase microstructure containing amorphous $\mathrm{SiO}$ plates and different carbon structures is formed in the $\mathrm{SiO} / \mathrm{C} / \mathrm{G}$ composites.

\section{Electrochemical Performances}

Figure 5 compares the charge/discharge profiles, cyclic capacity, and cyclic Coulombic efficiency of pristine $\mathrm{SiO}$ and as-prepared composites. As shown in Figure 5A, the pristine $\mathrm{SiO}$ anode delivers an initial discharge capacity of $2,318 \mathrm{mAh} \mathrm{g}^{-1}$, which is slightly less than its theoretical capacity of ca. $2,400 \mathrm{mAh} \mathrm{g}^{-1}$. The initial charge capacity of pristine $\mathrm{SiO}$ is only $1,285 \mathrm{mAh} \mathrm{g}^{-1}$, with the initial Coulombic efficiency is $55.4 \%$. This irreversible capacity loss is mainly due to the generation of inactive $\mathrm{Li}_{2} \mathrm{O}$ and $\mathrm{Li}_{4} \mathrm{SiO}_{4}$ in the initial discharging process. Comparatively, three composites exhibit lowered initial discharge capacity, being 1,259 $\mathrm{mAh} \mathrm{g}^{-1}$ for the SiO/C-700 composite, $965 \mathrm{mAh} \mathrm{g}^{-1}$ for the $\mathrm{SiO} / \mathrm{C} / \mathrm{G}-700$ composite, and 1,509 $\mathrm{mAh} \mathrm{g}^{-1}$ for the $\mathrm{SiO} / \mathrm{C} / \mathrm{G}-$ 900 composite. The much higher capacity for the SiO/C/G-900 composite than the $\mathrm{SiO} / \mathrm{C} / \mathrm{G}-700$ composite is related to the formation of a small amount of $\mathrm{Si}$, and the decrease of oxygen concentration at a pyrolysis temperature of $900^{\circ} \mathrm{C}$, which has been proven in Figures 2A,C. As also shown in Figure 5A, the lowered discharge potential of three composites in comparison with pristine $\mathrm{SiO}$ should be due to the amorphous carbon coated on the $\mathrm{SiO}$ plates, which is unbeneficial to the $\mathrm{Li}^{+}$diffusion to react with $\mathrm{SiO}$. As shown in Figure 5B, after 100 charge-discharge cycles, the $\mathrm{SiO} / \mathrm{C} / \mathrm{G}-700$ and $\mathrm{SiO} / \mathrm{C} / \mathrm{G}-900$ composites possess elevated discharge potential, which is a little higher than that of the $\mathrm{SiO} / \mathrm{C}-700$ composite.

From Figure 5C, both the $\mathrm{SiO} / \mathrm{C} / \mathrm{G}-900$ and $\mathrm{SiO} / \mathrm{C} / \mathrm{G}-700$ composites show stable cyclic performances. The SiO/C/G-900 composite presents an initial charge capacity of $963 \mathrm{mAh} \mathrm{g}^{-1}$, which increases up to maximum $1,073 \mathrm{mAh} \mathrm{g}^{-1}$ at 25 th cycle, and then slowly decreases to $950 \mathrm{mAh} \mathrm{g}^{-1}$ after 100 cycles. Therefore, the capacity retention relative to the first charge capacity is $98.7 \%$ at 100 th cycle for the $\mathrm{SiO} / \mathrm{C} / \mathrm{G}-900$ composite, which is much higher than those for pristine $\mathrm{SiO}(4.3 \%)$ and SiO/G-700 composite (52.7\%). Xia et al. (2019) improve the electrochemical performance of $\mathrm{SiO} @ \mathrm{C} /$ graphite shows a high capacity retention rate of over $91 \%$ after 100 cycles, which is lower than the $\mathrm{SiO} / \mathrm{C} / \mathrm{G}-900$ composite. For the $\mathrm{SiO} / \mathrm{C} / \mathrm{G}-700$ composite, the 100th charge capacity $\left(768 \mathrm{mAh} \mathrm{g}^{-1}\right)$ is even much higher than its initial capacity of $603 \mathrm{mAh} \mathrm{g}^{-1}$, while for the $\mathrm{SiO} / \mathrm{C}-700$ composite, the capacity shows fast fading after 60 cycles. Therefore, the graphite addition greatly improves the cycle stability of $\mathrm{SiO}$ plates with amorphous carbon coating.

From Figure 5D, three composites show a little improvement in the cyclic Coulombic efficiency in comparison with pristine $\mathrm{SiO}$. The highest initial Coulombic efficiency is $63.8 \%$ for the $\mathrm{SiO} / \mathrm{C} / \mathrm{G}-900$ composite. After several cycles, the Coulombic efficiency of SiO/C/G-900 and SiO/C/G-700 composites are stabilized at $98.7 \%$, slightly higher than those of pristine $\mathrm{SiO}$ and $\mathrm{SiO} / \mathrm{C}-700$ composite. The poor initial Coulombic efficiency originating from its low electrical conductivity and irreversible reaction during the first cycle (Choi et al., 2019).

Since the $\mathrm{SiO} / \mathrm{C} / \mathrm{G}-900$ composite shows the best electrochemical performances, Figure 6A further shows the selected cyclic charge/discharge profiles of $\mathrm{SiO} / \mathrm{C} / \mathrm{G}-900$ composite. There is no obvious change for the chargedischarge profiles at $2 \mathrm{nd}$, 5th, 50th, 100th cycles, indicating the good reversibility of the reactions in this composite anode. To investigate the lithiation/delithiation mechanism of the SiO/C/G-900 composite, the differential capacity plots at different cycles are depicted in Figure 6B. A weak cathodic peak at $0.60 \mathrm{~V}$ in the 1 st cycle is ascribed to the formation of SEI film and decomposition of electrolyte, contributing some irreversible 

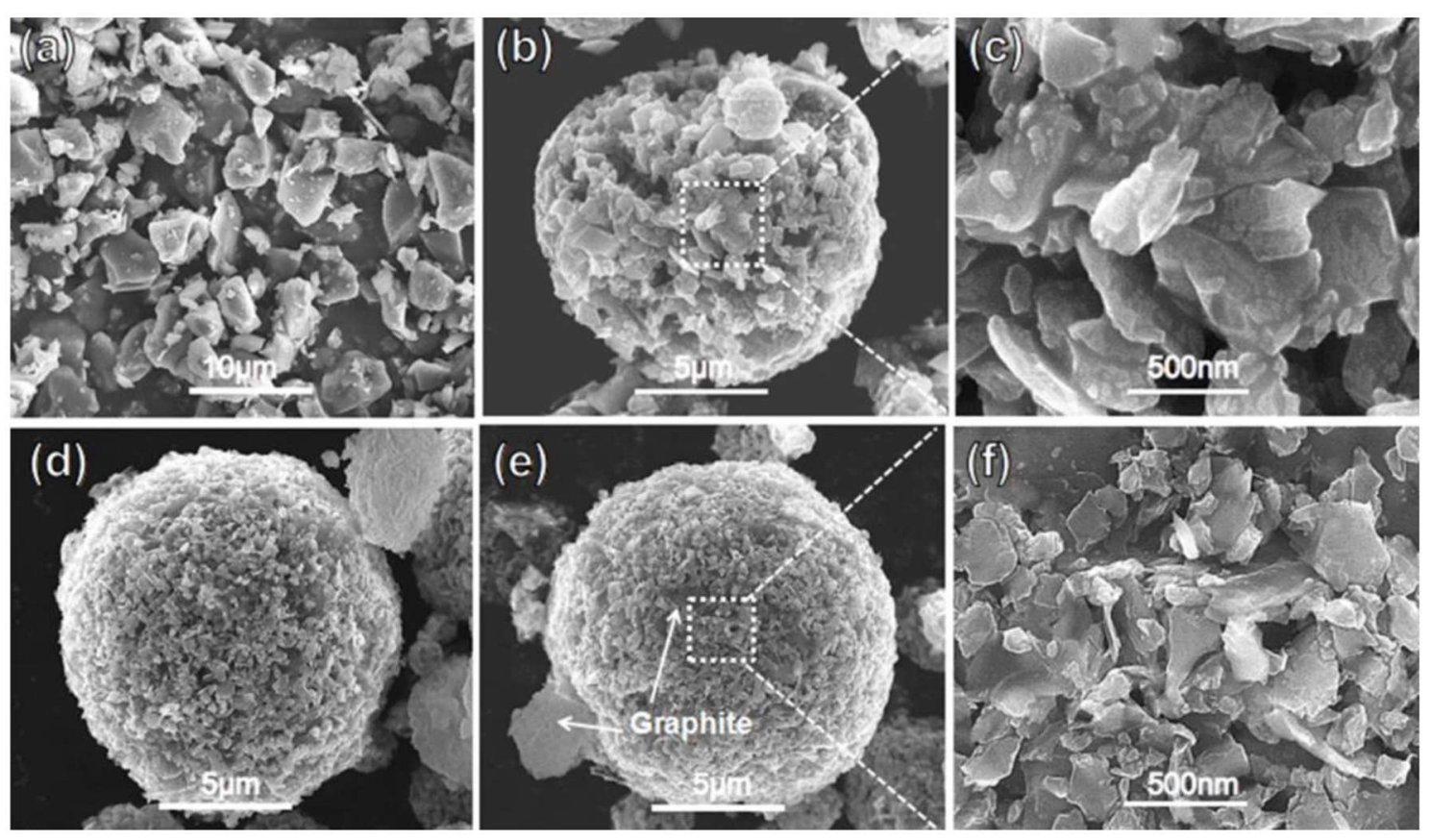

FIGURE 3 | SEM images of (a) Pristine SiO. (b,c) SiO/C-700 composite. (d) SiO/C/G-700 composite. (e,f) SiO/C/G-900 composite.
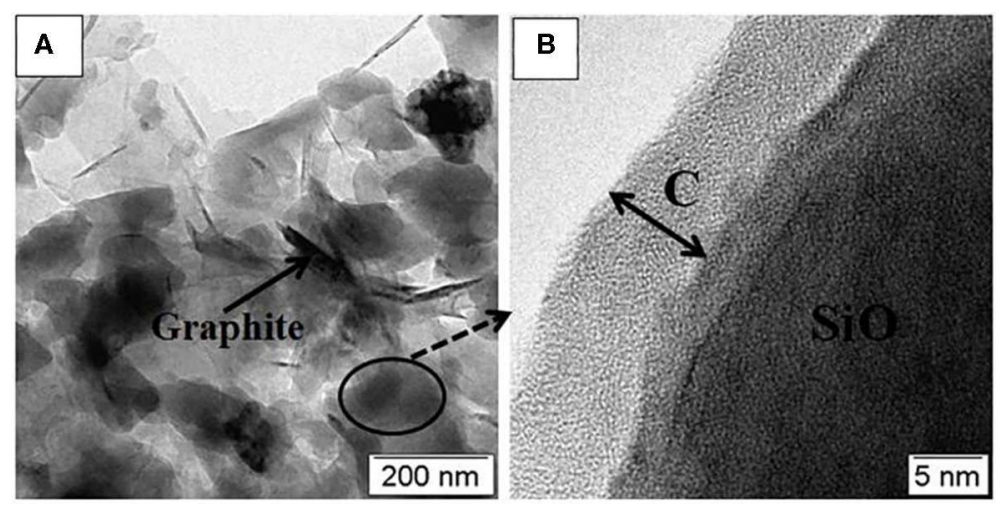

FIGURE 4 | (A,B) TEM images of the SiO/C/G-900 composite.

capacity (Zhou et al., 2013; Hubaud et al., 2015). Besides, the reduction peak at $0.24 \mathrm{~V}$ is attributed to the alloying of $\mathrm{Si}$ with $\mathrm{Li}^{+}$, which corresponds to two anodic peaks at $0.28 \mathrm{~V}$ and $0.47 \mathrm{~V}$, reflecting a two-step dealloying process (Tao et al., 2012; Xie et al., 2014). A pair of cathodic peak at $0.08 \mathrm{~V}$ and anodic peak at $0.14 \mathrm{~V}$ belongs to the lithium insertion and extraction process of graphite (Zhou et al., 2013; Hang et al., 2014). The overlapping peaks of the cyclic $\mathrm{dQ} / \mathrm{dV}$ profiles also indicate excellent cyclic stability for the $\mathrm{SiO} / \mathrm{C} / \mathrm{G}-900$ composite.

Figure $6 \mathrm{C}$ shows the good rate capability of the $\mathrm{SiO} / \mathrm{C} / \mathrm{G}-$ 900 composite. At $400 \mathrm{~mA} \mathrm{~g}^{-1}$, the composite exhibits stable reversible charge capacity of ca. $895 \mathrm{mAh} \mathrm{g}^{-1}$, which is a little lower than maximum charge capacity of $1,017 \mathrm{mAh} \mathrm{g}^{-1}$ at $100 \mathrm{~mA} \mathrm{~g}^{-1}$. The $\mathrm{SiO}_{\mathrm{x}} @ \mathrm{C}$ electrode exhibits rate capability with discharge capacity of approximately $946.7,751.7$ at 0.2 , and $0.4 \mathrm{~A} / \mathrm{g}$ (Cui et al., 2016), which is lower than $\mathrm{SiO} / \mathrm{C} / \mathrm{G}-$ 900 composite. Even at $1,000 \mathrm{~mA} \mathrm{~g}^{-1}$, a charge capacity of $670 \mathrm{mAh} \mathrm{g}^{-1}$ is maintained after 10 cycles. When the current density is back to $100 \mathrm{~mA} \mathrm{~g}^{-1}$ after 40 cycles, the charge capacity recovers to $980 \mathrm{mAh} \mathrm{g}^{-1}$. Combined with the corresponding charge/discharge profiles (Figure 6D) at different current densities, the $\mathrm{SiO} / \mathrm{C} / \mathrm{G}-900$ composite shows excellent rate capability.

As abovementioned, the $\mathrm{SiO} / \mathrm{C} / \mathrm{G}-900$ composite heated at $900^{\circ} \mathrm{C}$ shows high capacity, excellent cyclic stability, and rate capability. The higher pyrolysis temperature for the $\mathrm{SiO} / \mathrm{C} / \mathrm{G}-$ 900 composite than the $\mathrm{SiO} / \mathrm{C} / \mathrm{G}-700$ composite results in the formation of a small amount of Si crystals in the amorphous 

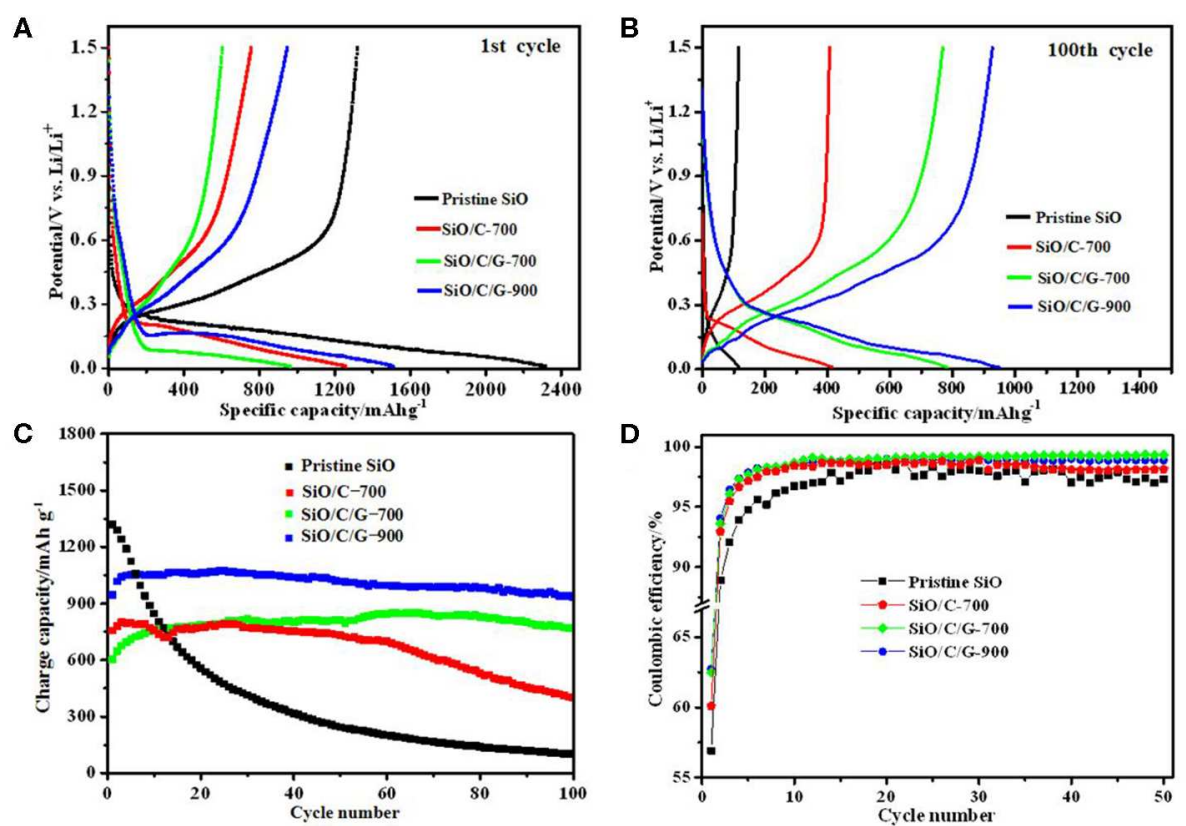

FIGURE 5 | Comparison of electrochemical performances of pristine SiO, SiO/C-700, SiO/C/G-700, and SiO/C/G-900 composites at 100 mA.g ${ }^{-1}$ : (A,B) The discharge-charge profiles at 1st and100th cycle. (C) cyclic capacity. (D) cyclic Coulombic efficiency.
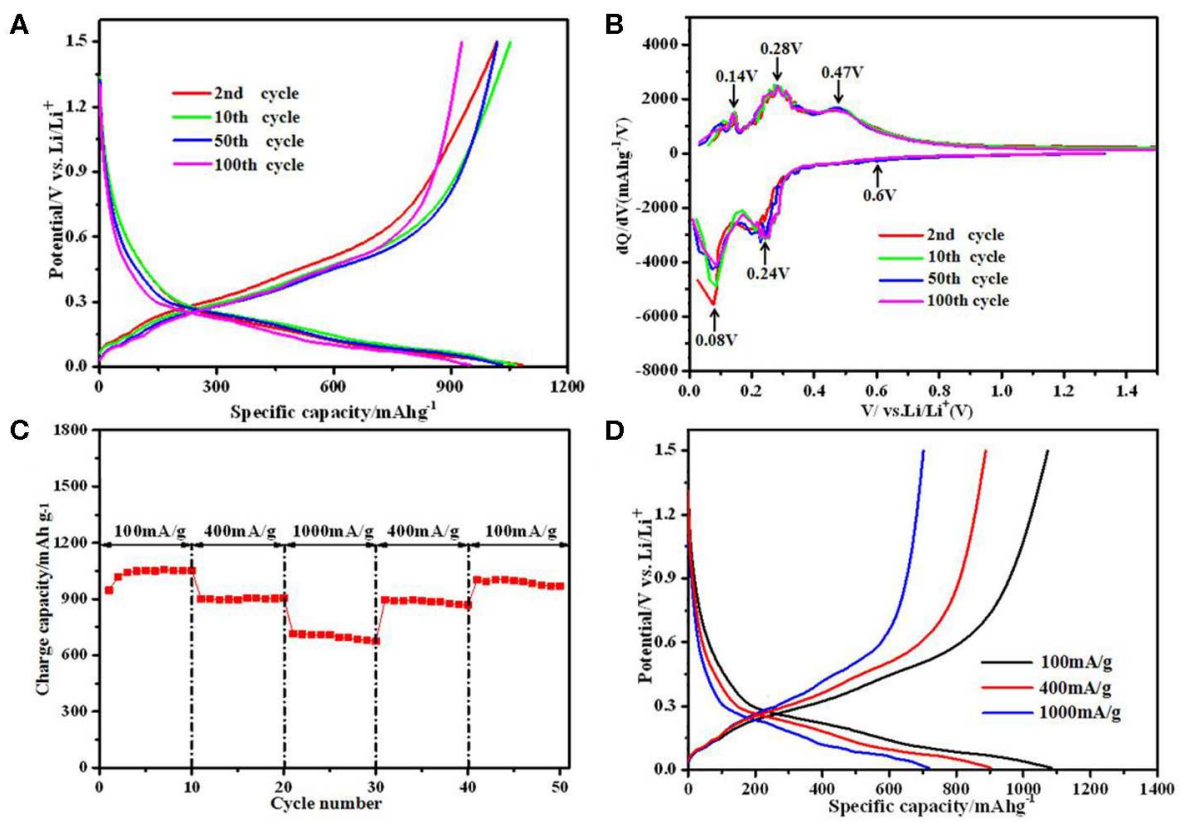

FIGURE 6 | Electrochemical performance of the SiO/C/G-900 composite: (A) The discharge-charge profiles. (B) differential capacity plots (C) rate capability. (D) discharge-charge profiles at different current densities.

$\mathrm{SiO}$ matrix, this is responsible for the increased capacity. Among three composites, the excellent cyclic stability of the $\mathrm{SiO} / \mathrm{C} / \mathrm{G}-900$ and $\mathrm{SiO} / \mathrm{C} / \mathrm{G}-700$ composites is mainly attributed to graphite sheets, which helps to form dense microstructure in the near-spherical composite particles. In contrast, the loose microstructure for the $\mathrm{SiO} / \mathrm{C}-700$ composite leads to fast capacity fading after tens of cycles. Therefore, this combination of amorphous carbon coating and graphite sheets could effectively buffer the volume change of $\mathrm{SiO}$ during repeatedly lithium insertion/extraction, and maintain the structural stability 
of the composite electrode. Previous literature reported the improvement of cyclic performances of $\mathrm{SiO}$ by compositing with different carbon materials (Cui et al., 2016; Xia et al., 2019). Comparatively, this work shows that better cyclic performances could be achieved by compositing hybrid carbon structure with $\mathrm{SiO}$.

\section{CONCLUSIONS}

We demonstrate a facile route to prepare high-performance $\mathrm{SiO}$-based composite anode. By mechanical milling, spray drying, and high-temperature pyrolysis, the obtained SiO/C/G900 composite exhibited an initial charge capacity ( $\sim 963$ $\mathrm{mAh} \mathrm{g}^{-1}$ at $\left.100 \mathrm{~mA} \mathrm{~g}^{-1}\right)$, excellent cyclic stability $(\sim 950$ $\mathrm{mAh} \mathrm{g}^{-1}$ over 100 cycles) and rate capability. The enhanced electrochemical performances are attributed to the unique composite microstructure of $\mathrm{SiO} / \mathrm{C} / \mathrm{G}$ composites, in which both amorphous carbon coating and the graphite sheets improve the conductivity as well as the stability of composite electrode during repeatedly charge-discharge process. Therefore, our work shows that this $\mathrm{SiO} / \mathrm{C} / \mathrm{G}$ composite is a promising candidate for the anode material of next-generation LIBs.

\section{REFERENCES}

Chang, W., Park, C., Kim, J., Kim, Y., Jeong, G., and Sohn, H. (2012). Quartz $\left(\mathrm{SiO}_{2}\right)$ : a new energy storage anode material for Li-ion batteries. Energ. Environ. Sci. 5:6895. doi: 10.1039/c2ee00003b

Choi, G., Kim, J., and Kang, B. (2019). Understanding limited reversible capacity of a sio electrode during the first cycle and its effect on initial coulombic efficiency. Chem. Mater. 31, 6097-6104. doi: 10.1021/acs.chemmater.9b01057

Cui, J., Cui, Y., Li, S., Sun, H., Wen, Z., and Sun, J. (2016). Microsized porous $\mathrm{SiO}_{\mathrm{x}} @ \mathrm{C}$ composites synthesized through aluminothermic reduction from rice husks and used as anode for lithium-ion batteries. ACS Appl. Mater. Inter. 8, 30239-30247. doi: 10.1021/acsami.6b10260

Fu, J., Liu, H., Liao, L., Fan, P., Wang, Z., Wu, Y., et al. (2018). Ultrathin Si/CNTs paper-like composite for flexible li-ion battery anode with high volumetric capacity. Front. Chem. 6:624. doi: 10.3389/fchem.2018.00624

Guo, C., Wang, D., Liu, T., Zhu, J., and Lang, X. (2014). A three dimensional $\mathrm{SiO}_{\mathrm{x}} / \mathrm{C} @ \mathrm{RGO}$ nanocomposite as a high energy anode material for lithium-ion batteries. J. Mater. Chem. A 2, 3521-3527. doi: 10.1039/C3TA13746E

Hang, T., Mukoyama, D., Nara, H., Yokoshima, T., Momma, T., Li, M., et al. (2014). Electrochemical impedance analysis of electrodeposited $\mathrm{Si}-\mathrm{O}-\mathrm{C}$ composite thick film on $\mathrm{Cu}$ microcones-arrayed current collector for lithium ion battery anode. J. Power Sources 256, 226-232. doi: 10.1016/j.jpowsour.2014.01.065

Hou, X., Zhang, M., Wang, J., Hu, S., Liu, X., and Shao, Z. (2015). High yield and low-cost ball milling synthesis of nano-flake $\mathrm{Si}_{2} \mathrm{SiO}_{2}$ with small crystalline grains and abundant grain boundaries as a superior anode for Li-ion batteries. J. Alloy. Compd. 639, 27-35. doi: 10.1016/j.jallcom.2015.03.127

Huang, X., Pu, H., Chang, J., Cui, S., Hallac, P. B., Jiang, J., et al. (2013). Improved cyclic performance of $\mathrm{Si}$ anodes for lithium-ion batteries by forming intermetallic interphases between Si nanoparticles and metal microparticles. ACS Appl. Mater. Inter. 5, 11965-11970. doi: 10.1021/am403718u

Hubaud, A. A., Yang, Z., Schroeder, D. J., Dogan, F., Trahey, L., and Vaughey, J. T. (2015). Interfacial study of the role of $\mathrm{SiO}_{2}$ on $\mathrm{Si}$ anodes using electrochemical quartz crystal microbalance. J. Power Sources 282, 639-644. doi: 10.1016/j.jpowsour.2015.02.006

Hwa, Y., Park, C., and Sohn, H. (2013). Modified SiO as a high performance anode for Li-ion batteries. J. Power Sources 222, 129-134. doi: 10.1016/j.jpowsour.2012.08.060

\section{DATA AVAILABILITY STATEMENT}

The datasets generated for this study are included in this article.

\section{AUTHOR CONTRIBUTIONS}

HW, RH, and RT designed the experiments and finished the writing of the manuscript. LH and WX completed the experiments and analyzed the data. LO and TS provided helpful suggestions on the preparation process of electrode materials. All authors have made a substantial and direct contribution to this work.

\section{FUNDING}

This work was financially supported by National Basic Research Program of China (Grant No. 2018YFB1502101), and the National Natural Science Foundation of China (Grant Nos. U1601212, 51727801), the Fund for Innovative Research Groups of the National Natural Science Foundation of China (Grant No. 51621001), and Natural Science Foundation of Guangdong Province (2016A030312011).

Jia, H., Zheng, J., Song, J., Luo, L., Yi, R., Estevez, L., et al. (2018). A novel approach to synthesize micrometer-sized porous silicon as a high performance anode for lithium-ion batteries. Nano Energy 50, 589-597. doi: 10.1016/j.nanoen.2018.05.048

Kataoka, R., Oda, Y., Inoue, R., Kitta, M., and Kiyobayashi, T. (2016). Highstrength clad current collector for silicon-based negative electrode in lithium ion battery. J. Power Sources 301, 355-361. doi: 10.1016/j.jpowsour.2015.10.009

Kim, J., Park, C., Kim, H., Kim, Y., and Sohn, H. (2011). Electrochemical behavior of $\mathrm{SiO}$ anode for Li secondary batteries. J. Electroanal. Chem. 661, 245-249. doi: 10.1016/j.jelechem.2011.08.010

Kim, M. K., Jang, B. Y., Lee, J. S., Kim, J. S., and Nahm, S. (2013). Microstructures and electrochemical performances of nano-sized $\mathrm{SiO}_{\mathrm{x}}(1.18 \leq \mathrm{x} \leq 1.83)$ as an anode material for a lithium(Li)-ion battery. J. Power Sources 244, 115-121. doi: 10.1016/j.jpowsour.2013.03.041

Krywko-Cendrowska, A., Strawski, M., and Szklarczyk, M. (2013). Low temperature electrodeposition of $\mathrm{SiOx}$ films photoactive in water solution. Electrochim. Acta 108, 112-117. doi: 10.1016/j.electacta.2013.06.112

Lee, M., Yoon, D., Lee, U. J., Umirov, N., Mukanova, A., Bakenov, Z., et al. (2019). The electrochemical performances of n-type extended lattice spaced Si negative electrodes for lithium-ion batteries. Front. Chem. 7:389. doi: 10.3389/fchem.2019.00389

Li, M., Li, J., Li, K., Zhao, Y., Zhang, Y., Gosselink, D., et al. (2013). $\mathrm{SiO}_{2} / \mathrm{Cu} /$ polyacrylonitrile- $\mathrm{C}$ composite as anode material in lithium ion batteries. J. Power Sources 240, 659-666. doi: 10.1016/j.jpowsour.2013.05.017

Li, M., Zeng, Y., Ren, Y., Zeng, C., Gu, J., Feng, X., et al. (2015). Fabrication and lithium storage performance of sugar apple-shaped $\mathrm{SiO}_{\mathrm{x}} @ \mathrm{C}$ nanocomposite spheres. J. Power Sources 288, 53-61. doi: 10.1016/j.jpowsour.2015.04.127

Liang, B., Liu, Y., and Xu, Y. (2014). Silicon-based materials as high capacity anodes for next generation lithium ion batteries. J. Power Sources 267, 469-490. doi: 10.1016/j.jpowsour.2014.05.096

Lv, P., Zhao, H., Gao, C., Du, Z., Wang, J., and Liu, X. (2015). $\mathrm{SiO}_{\mathrm{x}}$ $\mathrm{C}$ dual-phase glass for lithium ion battery anode with high capacity and stable cycling performance. J. Power Sources 274, 542-550. doi: 10.1016/j.jpowsour.2014.10.077

Lv, P., Zhao, H., Wang, J., Liu, X., Zhang, T., and Xia, Q. (2013). Facile preparation and electrochemical properties of amorphous $\mathrm{SiO}_{2} / \mathrm{C}$ composite as anode material for lithium ion batteries. J. Power Sources 237, 291-294. doi: 10.1016/j.jpowsour.2013.03.054 
Rahaman, O., Mortazavi, B., and Rabczuk, T. (2016). A first-principles study on the effect of oxygen content on the structural and electronic properties of silicon suboxide as anode material for lithium ion batteries. J. Power Sources 307, 657-664. doi: 10.1016/j.jpowsour.2016.01.003

Rahman, M. A., Song, G., Bhatt, A. I., Wong, Y. C., and Wen, C. (2016). Nanostructured silicon anodes for high-performance lithium-ion batteries. Adv. Funct. Mater. 26, 647-678. doi: 10.1002/adfm.201502959

Si, Q., Hanai, K., Ichikawa, T., Phillipps, M. B., Hirano, A., Imanishi, N., et al. (2011). Improvement of cyclic behavior of a ball-milled $\mathrm{SiO}$ and carbon nanofiber composite anode for lithium-ion batteries. J. Power Sources 196, 9774-9779. doi: 10.1016/j.jpowsour.2011. 08.005

Song, K., Yoo, S., Kang, K., Heo, H., Kang, Y., and Jo, M. (2013). Hierarchical $\mathrm{SiO}_{\mathrm{x}}$ nanoconifers for Li-ion battery anodes with structural stability and kinetic enhancement. J. Power Sources 229, 229-233. doi: 10.1016/j.jpowsour.2012.12.002

Su, X., Wu, Q., Li, J., Xiao, X., Lott, A., Lu, W., et al. (2014). Siliconbased nanomaterials for lithium-ion batteries: a review. Adv. Energy Mater. 4:1300882. doi: 10.1002/aenm.201300882

Tao, H., Fan, L., and Qu, X. (2012). Facile synthesis of ordered porous Si@C nanorods as anode materials for Li-ion batteries. Electrochim. Acta 71, 194-200. doi: 10.1016/j.electacta.2012.03.139

Vengudusamy, B., Grafl, A., and Preinfalk, K. (2014). Influence of silicon on the wear properties of amorphous carbon under dry and lubricated conditions. Tribol. Lett. 53, 569-583. doi: 10.1007/s11249-014-0295-2

Wang, D., Gao, M., Pan, H., Wang, J., and Liu, Y. (2014). High performance amorphous-Si@SiO $\mathrm{S}_{\mathrm{X}} / \mathrm{C}$ composite anode materials for Li-ion batteries derived from ball-milling and in situ carbonization. J. Power Sources 256, 190-199. doi: 10.1016/j.jpowsour.2013.12.128

Wang, J., Wang, C., Zhu, Y., Wu, N., and Tian, W. (2015). Electrochemical stability of optimized $\mathrm{Si} / \mathrm{C}$ composites anode for lithium-ion batteries. Ionics 21, 579-585. doi: 10.1007/s11581-014-1331-9

Wang, J., Zhao, H., He, J., Wang, C., and Wang, J. (2011). Nano-sized $\mathrm{SiO}_{\mathrm{x}} / \mathrm{C}$ composite anode for lithium ion batteries. J. Power Sources 196, 4811-4815. doi: 10.1016/j.jpowsour.2011.01.053

Wu, H. Y., Hon, M. H., Kuan, C. Y., and Leu, I. C. (2014). Preparation of $\mathrm{TiO}_{2}(\mathrm{~B})$ nanosheets by a hydrothermal process and their application as an anode for lithium-ion batteries. J. Electron. Mater. 43, 1048-1054. doi: 10.1007/s11664-013-2951-y

Xia, M., Li, Y., Wu, Y., Zhang, H., Yang, J., Zhou, N., et al. (2019). Improving the electrochemical properties of a SiO@C/graphite composite anode for highenergy lithium-ion batteries by adding lithium fluoride. Appl. Surf. Sci. 480, 410-418. doi: 10.1016/j.apsusc.2019.02.207

Xiao, L., Wu, D., Han, S., Huang, Y., Li, S., He, M., et al. (2013). Self-assembled $\mathrm{Fe}_{2} \mathrm{O}_{3}$ /graphene aerogel with high lithium storage performance. ACS Appl. Mater. Interfaces 5, 3764-3769. doi: 10.1021/am400387t

Xie, J., Wang, G., Huo, Y., Zhang, S., Cao, G., and Zhao, X. (2014). Nanostructured silicon spheres prepared by a controllable magnesiothermic reduction as anode for lithium ion batteries. Electrochim. Acta 135, 94-100. doi: 10.1016/j.electacta.2014.05.012
Xu, Q., Sun, J., Li, G., Li, J., Yin, Y., and Guo, Y. (2017). Facile synthesis of a $\mathrm{SiO}_{\mathrm{x}}$ /asphalt membrane for high performance lithium-ion battery anodes. Chem. Commun. 53, 12080-12083. doi: 10.1039/C7CC05816K

Yamada, M., Uchitomi, K., Ueda, A., Matsumoto, K., and Ohzuku, T. (2013). Performance of the "SiO"-carbon composite-negative electrodes for highcapacity lithium-ion batteries; prototype 14500 batteries. J. Power Sources 225, 221-225. doi: 10.1016/j.jpowsour.2012.10.046

Yamamura, H., Nakanishi, S., and Iba, H. (2013). Reduction effect of irreversible capacity on $\mathrm{SiO}$ anode material heat-reacted with $\mathrm{Fe}_{2} \mathrm{O}_{3}$. J. Power Sources 232, 264-269. doi: 10.1016/j.jpowsour.2013.01.038

Yang, H., Lee, D. I., Kang, N., Yoo, J., Myung, S., Kim, J., et al. (2018). Highly enhancement of the $\mathrm{SiO}_{\mathrm{x}}$ nanocomposite through Ti-doping and carboncoating for high-performance Li-ion battery. J. Power Sources 400, 613-620. doi: 10.1016/j.jpowsour.2018.08.065

Yom, J. H., Hwang, S. W., Cho, S. M., and Yoon, W. Y. (2016). Improvement of irreversible behavior of $\mathrm{SiO}$ anodes for lithium ion batteries by a solid state reaction at high temperature. J. Power Sources 311, 159-166. doi: 10.1016/j.jpowsour.2016.02.025

Yu, B. C., Hwa, Y., Kim, J. H., and Sohn, H. J. (2014). A new approach to synthesis of porous $\mathrm{SiO}_{\mathrm{x}}$ anode for $\mathrm{Li}$-ion batteries via chemical etching of Si crystallites. Electrochim. Acta 117, 426-430. doi: 10.1016/j.electacta.2013.11.158

Yuan, X., Xin, H., Qin, X., Li, X., Liu, Y., and Guo, H. (2015). Selfassembly of $\mathrm{SiO} /$ reduced graphene oxide composite as high-performance anode materials for Li-ion batteries. Electrochim. Acta 155, 251-256. doi: 10.1016/j.electacta.2014.12.124

Zeilinger, M., Kurylyshyn, I. M., Häussermann, U., and Fässler, T. F. (2013). Revision of the Li-Si phase diagram: discovery and single-crystal X-ray structure determination of the high-temperature phase $\mathrm{Li}_{4.11} \mathrm{Si}$. Chem. Mater. 25, 4623-4632. doi: 10.1021/cm4029885

Zhang, Y., Guo, G., Chen, C., Jiao, Y., Li, T., Chen, X., et al. (2019). An affordable manufacturing method to boost the initial Coulombic efficiency of disproportionated SiO lithium-ion battery anodes. J. Power Sources 426, 116-123. doi: 10.1016/j.jpowsour.2019.04.032

Zheng, X., and Li, J. (2014). A review of research on hematite as anode material for lithium-ion batteries. Ionics 20, 1651-1663. doi: 10.1007/s11581-014-1262-5

Zhou, X., Tang, J., Yang, J., Xie, J., and Ma, L. (2013). Silicon@carbon hollow core-shell heterostructures novel anode materials for lithium ion batteries. Electrochim. Acta 87, 663-668. doi: 10.1016/j.electacta.2012.10.008

Conflict of Interest: The authors declare that the research was conducted in the absence of any commercial or financial relationships that could be construed as a potential conflict of interest.

Copyright (C) $2020 \mathrm{Hu}$, Xia, Tang, Hu, Ouyang, Sun and Wang. This is an open-access article distributed under the terms of the Creative Commons Attribution License (CC $B Y)$. The use, distribution or reproduction in other forums is permitted, provided the original author(s) and the copyright owner(s) are credited and that the original publication in this journal is cited, in accordance with accepted academic practice. No use, distribution or reproduction is permitted which does not comply with these terms. 